\title{
7. \\ UGLED NA PONUDU: \\ INTELEKTUALCI, GRAĐANI I \\ REVOLUCIONARI
}

\section{Tatjana Rosić}

UDK: $316.344 .32: 171$

Sažetak: Angažman novih intelektualnih elita koje se tokom devedesetih godina dvadesetog veka i posle dvehiljadite formiraju na postjugoslovenskim prostorima se, iz brojnih razloga, pokazao nedostatnim: zauzeti investiranjem u svoje karijere u širem kontekstu globalnog kulturnog tržišta intelektualci su doprineli porazu građanskog koncepta društvenog angažmana i neuspehu brojnih pokušaja reforme građanske platforme kritičkog mišljenja. Ipak, ostali su privrženi preživelim oblicima građanskog društvenog angažmana i njihovom konformizmu. Autorska kolumna predstavlja privilegovani medijski žanr takvog angažmana i preciznu formulu brze transformacije simboličke u političku moć na postjugoslovenskim prostorima. Tek početkom druge decenije dvadeset prvog veka javili su se glasovi pobune protiv ovakvog stanja i protiv sticanja simboličkog kapitala pristajanjem na pravila neoliberalnog tržišno-kulturnog kapitalizma. Teoretičari mlađih generacija zalažu se za prevazilaženje traumatske investicije u procesu sticanja simboličkog kapitala jer je po njima to uvek investicija u prošlost, vođena nekrofilnom politikom koju su uspostavili kolonizatori a ne žrtve. Otuda se u novim konceptima političkog angažmana ne razmatra Agambenov pojam "golog života" već mogućnosti stvaranja drugačijih društvenih i političkih stvarnosti. Sve to ukazuje na potrebu rekonstituisanja figure intelektualca-revolucionara u postjugoslovenskom kulturnom prostoru koja bi trebalo da se suoči sa budućnošću slobode i da spreči intelektualne kalkulacije sopstvenom traumom, mazohizam sticanja simboličkog kapitala, transakcije ugledom, kao i transfere iz jedne u drugu značajnu tačku društvene moći. Novi angažman trebalo bi da se temelji u pobuni koja će zbuniti medije i onemogućiti njihovu dominaciju nad procesom sticanja intelektualnog i simboličkog kapitala.

Ključne reči: intelektualac, građanin, revolucionar, globalizacija, postjugoslovenski kulturni prostor, masovni mediji, angažman, simbolički kapital

The revolution will not be televised, will not be televised, Will not be televised, will not be televised. The revolution will no be re-run brothers; The revolution will be live. 
uvena Marksova definicija kretanja kapitala kao nužnosti kapitalističkog načina proizvodnje, u epohi globalizacije pokazala se, kao i neke druge Marksove opaske, $G$ proročkom. Za razliku od feudalnog poseda i bogatstva u nekretninama osobina je kapitalističke matrice proizvodnje da se novac i roba otuđuju kako bi se obnovio proizvodno-profitni ciklus; tek je neprekidno kretanje ono što kapital čini kapitalom a kapitalističko društvo društvom ideje o progresu i napretku uprkos sveopštoj eksploataciji. U epohi globalizacije Marksova krilatica o kretanju kapitala dobija svoju planetarnu podršku. Iako je u svom putovanju planetom kapital zapravo neka vrsta slepog putnika koji se "švercuje" u okviru ideoloških, političkih, ekonomskih i kulturoloških diskursa globalizacije - budući da se u okviru tih diskursa slavi politika razmene a ne kupoprodaje, što je apsurdno - on postaje najviše očekivani i najrađe dočekivani putnik sveta. Bez obzira na specifičnosti različitih kulturološko-društvenih praksi, od kojih bi neke mogle usporiti i/ili onemogućiti kretanje kapitala, brzina postaje, kako na to ukazuje Pol Virilio, jedna od ključnih osobina savremenog globalnog života. ${ }^{1}$ Sve veće njegovo ubrzanje omogućeno je savremenim masovnim medijima: lakša komunikacija, multikulturalnost, ekspanzija društvenih mreža i novi sociološki fenomeni vezani za native digitals, odnosno za generacije odrasle uz elektronske medije i kompjutere, samo su kolateralna šteta globalnog a ipak kolonijalnog imperativa cirkulacije novca i roba koji dominira planetom.

Krajem XX veka, međutim, neoliberalno globalno tržište se iz obećanog sna o slobodi preobratilo u noćnu moru krvave akumulacije prvobitnog kapitala, razotkrivajući totalitarističku paradigmu ovog kretanja bez odmora u kome se stvaraju nove transnacionalne ali i nacionalne elite uz obnavljanje dramatičnih klasnih razlika. Kako primećuje sociolog Ričard Senet:

Novi institucionalni poredak odbacuje odgovornost, a sopstvenu ravnodušnost imenuje kao slobodu za pojedince ili grupe koji obitavaju na periferiji. Ravnodušnost je porok politike koja je proizašla iz novog kapitalizma. ${ }^{2}$

Senet je u svojim istraživanjima pre svega fokusiran na kulturu novog kapitalizma u SAD ali ona se sa podjednakom valjanošću može primeniti i na Evropu i njene najbogatije članice:

Vekovima su Evropa i Severna Amerika predstavljale brend stranaca kao veliko, zastrašujuće prisustvo. Danas je, kao i nekada, stranac postao simbol pomoću kog ljudi mogu iskazivati svakakve zebnje. Uz dugovečnu predrasudu i političko osvajanje poena, sliku o imigrantima danas uobličava i kratkotrajna, nestabilna birokratija. (...) U tom iskrivljenom zamišljanju ljudi ne primećuju kako malo mogu doprineti sigurnosti svog posla time što će goniti slabe autsajdere. $^{3}$

Pri tome javnost već dugo ostaje nema na izazove nove bede i ukidanja građanskih sloboda koje, širom Evrope, nestaju uporedo sa zakonskim ukidanjem ili znatnim redukovanjem osnovnih pretpostavki welfare države. Nije začuđujuće to da postupna redukcija liberalnih zakonskih regulativa zapadnoevropskih welfare država (poput Holandije i Švajcarske npr.) jeste vezana upravo za politiku prema migrantima i političkim azilantima: mnogi od zako-

\footnotetext{
Pol Virilio, Mašine vizije, Novi Sad 1993., 9-15.

2 Ričard Senet, Kultura novog kapitalizma, Beograd 2007., 135.

3 Isto, 137.
} 
na traže strožu politiku prema ovim grupama u rasejanju koje, navodno, ugrožavaju “domaće stanovništvo" i njihovo pravo na rad i državnu potporu.

Jasno je da u globalnom kretanju kapitala stradaju kako zemlje trećeg sveta tako i sam pojam "trećeg sveta" čija se geostrateška i ekonomska referentnost menja. Pojam trećeg sveta obuhvata danas, uz jedan prećutni i nikad obelodanjeni javni konsenzus, ne samo zemlje Afrike i Azije nego i neke od zemalja koje pretenduju da postanu članice EU - ili su to već postale. S druge strane, nove kolonijalne sile žurno zauzimaju mesto na mapi novog odmeravanja snaga: Kina i Rusija sada imaju svoje kolonijalne pretenzije i svoje planove u grozničavom obrtu kapitala. Ova situacija najavljuje i stvaranje novog, četvrtog sveta - onog koji će na geopolitičkoj mapi pripasti potpuno obespravljenim zemljama i pojedincima koji su njihovi državljani, onima koji će u međunarodnom pravu i političkim dogovorima imati ulogu subalterna čiju nam je sudbinu, vezanu pre svega za indijski političko-kulturološki kontekst, detaljno predočila feministička teoretičarka indijskog porekla Gajatri Čakravorti Spivak, razradivši Gramšijev pojam subalterna u kontekstu nove kolonizacije trećeg sveta koja se odigrava u savremenom globalnom društvu. ${ }^{4}$

U situaciji obnavljanja kolonijalnih pretenzija u kojoj se neoliberalno tržište obećane demokratije razotkriva kao tržište jeftine radne snage i novih oblika eksploatacije čini se da je figura intelektualca izgubila svoj društveni značaj i svrhu. Upravo zbog toga nikada se nije činilo potrebnijim da se figura intelektualca re-konstituiše: ovaj projekta čini se urgentnim projektom savremenog sveta oko koga se okupljaju različiti interesi i napori. Na potrebu obnavljanja platforme kritičkog mišljenja ukazuju tokom poslednje decenije XX i prve decenije XXI veka mnogi teoretičari kulturnih promena u okviru novog društva globalnog neoliberalnog kapitala. Sociolog poljskog porekla Zigmunt Bauman upotrebljava termin "fluidni strah" kako bi označio stanje permanentnog zastrašivanja kojim se novi kapital služi kako bi učvrstio svoje pozicije i koje prodire u sve društvene prakse savremenosti. Fluidnost straha ogleda se u nemoći da ga konkretno pripišemo određenom, realnom uzroku: strah je postao stalno stanje u kome je sve potencijalna pretnja, a njegova je glavna osobenost neuhvatljivost realnog razloga za strah koja u odsustvu realne opasnosti prožima naše aktivnosti, pretvarajući sve u potencijalnu opasnost. Bauman ukazuje na parališući momenat pretnje koju fluidni strah izaziva u našem ličnom ali i u društvenom životu. $\mathrm{O}$ tome raspravljaju, u različitim varijacijama, i drugi teoretičari društva masovnih medija. ${ }^{5}$ Američki teoretičar medija i obrazovanja Anri Žiro koristi, u te svrhe, termin "kultura straha”, kako bi označio specijalne medijske i edukativne strategije koje SAD primenjuju posle 11. septembra u svom naporu da svakog stranca, tj. Drugog predstave kao potencijalnog neprijatelja/teroristu i na taj način pojačaju osećaj animoziteta i teskobe koji vlada društvom. ${ }^{6}$ Žiro ukazuje na to da nije čudno što medijskom sferom "kulture straha" vladaju slike apokaliptičkog kraja civilizacije i poziva, kao i Daglas Kelner na razvijanje medijske pedagogije kao posebne discipline koja bi nam pomogla da adekvatno "čitamo" i "dekodiramo" ideološke poruke koje ovakvi medijski sadržaji nose. ${ }^{7}$ Polazeći upravo od apokaliptičkih sadržaja koji prate predstavljanje političkih i ekonomskih događaja u eri globalizacije i Naomi Klajn, američka teoretičarka razvija koncept "doktrine šoka” kojim nastoji da razotkrije strategije društveno-političke paralize posredstvom koje savremeni kapitalizam

\footnotetext{
Gajatri Čakravorti SpIvak, Teorija postkolonijalnog uma, Beograd 2003., 350-456.

Zigmunt Bauman, Fluidni strah, Novi Sad 2010.

Henry A. Giroux, Beyond the Spectacle of Terrorism, London 2006., 1-16.

Daglas Kelner, Medijska kultura, Beograd 2004., 9-25.
} 
ostvaruje svoju moć u zemljama Latinske Amerike i trećeg sveta, uz permanentnu pretnju upućenu siromašnima i najsiromašnijima. ${ }^{8}$

Iako ovakvih teorijskih "apela" na društvenu svest ima sve više, čini se da je projekat ponovnog uspostavljanja platforme kritičkog mišljenja započet prekasno. Kao da smo već nepovratno suočeni sa posledicama jednog procesa koji u svetu izaziva niz krvoprolića i nerešivih konflikata među kojima su slučaj Sirije i Ukrajine najkrvaviji, a slučaj sukoba Izraela i Palestine najviše iscrpljujući. Ovim bi se sukobima mogli pridružiti i nedavni sukobi u Bosni i Hercegovini za koje se ne zna koliko će trajati i na koji će se način završiti. Spisak zemalja i gradova koji su spremni da se revolucionarnim putem suprotstave kulturi straha i njenim demonima čini se sve dužim; ne bi trebalo zaboraviti da je na tom spisku i veliki broj "podeljenih" gradova poput npr. Skoplja i Sarajeva koji žive sličnu političku dramu kroz koju je posle II svetskog rata prolazio Berlin, uprkos tome što na njihovim ulicama još uvek nije podignut zid koji razdvaja (uz izuzetak Izraela gde tih zidova ima mnogo.) Otuda aktuelni politički i oružani sukobi koji za neke imaju formu građanskog rata dok ih neki zovu "novim revolucijama" kao da neutrališu insistiranje na obnavljanju građanske platforme kritičkog mišljenja: ono što se u kontekstu "novih revolucija" očekuje jeste konkretni angažman intelektualca u borbi za društvenu promenu i pobunu. Intelektualac neokolonijalnog globalnog sveta trebalo bi da bude i revolucionar, onaj koji u svom delovanju spaja praksu kritičkog mišljenja i praksu društveno angažovanog delovanja, ukidajući raskol, uvek konformistički, između te dve međusobno otuđene iako međusobno uslovljene prakse.

Jasno je da se ovaj zahtev za re-uspostavljanjem figure intelektualca-revolucionara obnavlja upravo u trenutku poraza reformističke građanske uloge intelektualca koji je kroz negovanje figure individualizma (u različitim varijacijama) imao zadatak da održi sveprisutnim i aktuelnim zadatak kritičkog mišljenja za društvo i o društvu. Ovaj je građanski intelektualac skoro zaćutao upravo u trenutku u kome je postalo evidentnim da on taj zadatak već jako dugo nije obavljao ili nije mogao obavljati kako bi trebalo.

Važno je istaći kako se zahtev za re-konstituisanjem figure intelektualca-revolucionara ističe upravo u trenutku kada na istorijsku scenu onoga što se do sada moglo smatrati "socijalno bezbednim" zapadnim svetom stupa agambenovska figura "golog života". ${ }^{9}$ Kada se, dakle, nekadašnje stanje nacističkih koncentracionih logora u kojima je jedinka bila svedena samo i jedino na svoju biološku egzistenciju, i kada se samo o toj egzistenciji imalo misliti uz ukidanje svih humanističkih koncepata društvene reforme, posle skoro pola veka, povampirilo i postalo globalnim fenomenom koji spaja sve kontinente? Postavlja se pitanje zbog čega se apel za rekonstituisanjem građanske platforme kritičkog mišljenja nije ustanovio pre ovog trenutka? Može li se imati poverenja u građane kao intelektualno odgovorne članove zajednice i u intelektualce kao građane koji briguju dobrobit svoje zajednice da odgovore adekvatno na strašnu sliku "golog života" koja je danas sveprisutna, pogotovo u medijima. Ko je spreman da odbaci umerenost reformističke građanske matrice intelektualnog delovanja i da prihvati revolucionarnu odgovornost? Kada i kako se ta promena odigrava i odigrava li se uopšte? I šta u međuvremenu radi građanska inteligencija, navikla na korišćenje konformističkog raskola između teorije i prakse društvene promene?

\footnotetext{
8 Naomi Klajn, Doktrina šoka: procvat kapitalizma katastrofe, Beograd 2009., 9-31.

9 Đorđo Agamben, Homo sacer: suverena moć i goli život, Loznica 2013.
} 
U situaciji medijski prisutnog "golog života" globalizacije i "novih revolucija" koje se rađaju u njegovu odbranu (puku odbranu) otvara se čitav niz pitanja, kako na globalnom tako na regionalnom i lokalnom nivou. Pokušaćemo u ovom radu da se usredsredimo pre svega na način na koji su na istorijski izazov "golog života" odgovorili intelektualci u Srbiji i državama postjugoslovenskog kulturnog prostora, onim koje prolaze kroz tzv. tranziciju ili su je navodno tek prošle, suočavajući se sa svim izazovima neokolonijalno investiranog kapitala u kretanju.

\section{Investicija, transakcija i građanski status quo: mazohizam sticanja}

U svojoj izvrsnoj knjizi $O$ škrtosti i o nekim sa njom povezanim stvarima Mladen Dolar nam ukazuje na askezu škrtosti kao na naličje rasipnog konzumerizma savremenog kapitalizma. Po Dolaru upravo je mazohizam škrtosti ono nesvesno u kome obitava kapitalistička želja - sasvim suprotno tvrdnji da je obnavljanje nesvesnog i raspusnosti strastvene želje osnova za duh sticanja i potrošnje u okviru Delezove koncepcije šizofrenog kapitalizma. Iako oba autora, i Delez i Dolar, ukazuju na podvojenu i šizofrenu prirodu savremenog investiranja, Dolar tvrdi da je ta podvojenost utemeljena u patnji škrtosti kao najveće strasti, a ne u raspusnosti strastvene želje. ${ }^{10}$ Sličan fenomen dešava se i u savremenim intelektualnim svedočenjima o raspadu Jugoslavije tokom devedesetih godina XX veka, pa i o konstituisanju postjugoslovenskog kulturnog prostora: ulog tog svedočenja jeste sećanje na sopstvenu traumu/patnju a ne vera u obnavljanje kulturne komunikacije i političke normalizacije, ne želja za prekidom rata već mazohističko obnavljanje sećanja na njegove žrtve.

Raspad Jugoslavije dao je priliku da se detektuje uloga intelektualca u zemljama koje su se iznenada suočile sa sasvim novim političkim i društvenim izazovima. Intelektualci sa postjugoslovenskih kulturnih prostora nisu morali samo da svedoče već i da prevode sopstvene traume (kao i traume drugih) na jezik prepoznatljiv i razumljiv globalnoj kulturnoj zajednici: u tom prevođenju, u pristajanju na to prevođenje, ma koliko ono bilo nemoguće (i to ne samo iz psihoanalitičke perspektive), ogleda se zapravo krucijalna investicija u procesu sticanja novog simboličkog kapitala u okviru globalne kulturne zajednice na koju su intelektualni pobunjenici i odmetnici sa ovih prostora - nevoljno ili ne - pristali u ime sopstvene traume. Uz jednu bitnu napomenu: proces prevođenja nije se odigravao samo na relaciji lokalnih postjugoslovenskih državnih zajednica naspram globalne političke zajednice velikih sila i vice versa. Taj se proces nastavlja i danas, ali na jednoj sasvim drugoj relaciji: prostornu osu zamenila je vremenska osa duž koje se za nove generacije nekadašnji događaji, kao i nekadašnja država SFRJ, tumače i prevode u diskurs "razumljiv" novim generacijama, onima koje se rata na prostorima bivše SFRJ kao i SFRJ same više ni ne sećaju. Knjige poput Kulture laži Dubravke Ugrešić ili Zone prelaska Borisa Budena najbolji su (kao i najlucidniji) primeri ovakvog intelektualnog angažmana i prakse. Investicija u napor razumevanja kao i u kulturu sećanja bila je, dakle, ključna za sticanje istinskog simboličkog kapitala koji bi nekog legitimirao za tumača nove stvarnosti na postjugoslovenskim kulturnim prostorima na kraju XX i početku XXI veka.

10 Mladen Dolar, O škrtosti i o nekim sa njom povezanim stvarima, Zagreb 2009., 47-62. 
Istina je da je izvestan mazohizam uvek primeren prirodi kapitalističkog sticanja. Razmotrimo na trenutak šta nam o savremenoj ulozi intelektualca govori Burdijeova teorija društvenih polja - teorija koja precizno ukazuje na klasne razlike u načinu formiranja simboličkog kapitala, razmatrajući jednu građansku, reformističku paradigmu intelektualne odgovornosti. Teorija "društvenih polja" francuskog sociologa Pjera Burdijea ukazuje na način sticanja "simboličkog kapitala" - koji je pored pojma "habitusa" ključni pojam koji je Burdije uveo u sociološke i kulturološke studije. Ono što je pre svega interesantno u okviru ove Burdijeove teorije jeste činjenica da se u društvu kretanja novca i roba prepoznaju i drugačiji oblici kapitala koji nemaju direktnu ili na prvi pogled prepoznatljivu ekonomsku ekvivalencu. Ono što je, međutim, zajedničko običnom i simboličkom kapitalu jeste činjenica da je simbolički kapital obeležen klasnom hijerarhijom društva koja, po Burdijeu, na izvesni način određuje kako habitus pojedinca tako i potencijal i mogućnosti sticanja simboličkog kapitala. ${ }^{11}$ To znači da će se pojedinac, čak i ako poreklom ne pripada hegemonim elitama, nastojati da im se priključi i da svoju društvenu inkluziju ostvari posredstvom stečenog ili posredovanog simboličkog kapitala. Burdijeova koncepcija simboličkog kapitala na izvestan je način ne-gramšijevska: simbolički kapital stečen poreklom, obrazovanjem i talentom je neka vrsta "ulaznice" za društvenu inkluziju u više slojeve budući da je, po Burdijeu, polje društvene moći uvek hijerarhijski nadređeno društvenim poljima nauke i umetnosti tako da npr. "u polju moći (...) književno polje zauzima podređeno mesto". ${ }^{2}$

Burdijeova teorija sticanja i transformacije simboličkog i intelektualnog kapitala sigurno nema mnogo veze sa aktuelnim revolucionarnim rešenjima društvene promene u "pobunjenim gradovima" širom sveta. Ipak i simbolički kapital, po Burdijeu, počiva na zakonu kretanja i investicije. Teorija "društvenih polja" ukazuje zapravo na "fragmentarizaciju" i kontekstualizaciju onoga što tradicionalno smatramo poljem autonomne intelektualne/ umetničke vrednosti i autorstva: u tom polju zapravo učestvuju kao podskupovi posebna interesna i esnafska polja u čijem prostoru npr. jedan pisac obitava ukoliko želi da se inicira u grupu "nacionalno značajnih pisaca" ili "avangardnih pisaca" ili "društveno angažovanih pisaca”. Društvena promocija svake od nabrojanih grupa rezultat je, pak, složenog procesa u kome istovremeno učestvuju, pored samih pisaca, i književni kritičari, profesori književnosti, članovi raznih udruženja i žirija i, konačno, mediji i štampa. U tom složenom procesu pisac na izvestan način prihvata situaciju u kojoj uzima učešće, na različite načine, u radu raznovrsnih interesnih esnafskih grupa. Taj niz investicija u stvaranju simboličkog kapitala biće piscu vraćen posle izvesnog vremena sa kamatama: pisac će postepeno sticati sve veći ugled i njegovo će delo biti sve više na ceni. ${ }^{13}$ Ukoliko neko još uvek veruje u blagonaklonu velikodušnost društva koje se nalazi u potrazi za autentičnim umetničkim i intelektualnim vrednostima, taj je u zabludi. Nema nikog pozvanijeg od pisca da o tome svedoči.

I zaista, ako se pogledaju dnevnici velikih imena srpske i/ili jugoslovenske književnosti, videće se da su naši pisci oduvek bili instiktivno svesni efikasnog delovanja Burdijeove teorije društvenih polja: njihov profesionalni i životni put svedoči o nizu investicija u aktivnosti koje na prvi pogled nisu imale nikakve direktne veze sa samim činom pisanja ali su, dalekosežno, doprinele stvaranju simboličkog kapitala koji bi se vezivao za ime određenog pisca ili spisateljice. Ukoliko pročitamo Dnevnike Aleksandra Tišme možemo npr. pratiti

\footnotetext{
11 Pjer Burdije, Pravila umetnosti: geneza i struktura polja književnosti, Novi Sad 2003., 303-331.

12 Isto, 303.

13 Isto, 321-323.
} 
čitavu nit diskusije o odnosu građanske ideje intelektualnog rada i zahteva za angažmanom koji je bio u sukobu sa tom idejom. ${ }^{14}$ Ipak, većina pisaca, za razliku od Tišme, nije bila spremna da u javnosti prizna svoje kalkulacije u prostoru društvene borbe za sticanje simboličkog kapitala: najčešće su one bile shvaćene kao deo šire društvene delatnosti umetnika kao višestruko angažovane intelektualne figure društva. U suštini, ta višestruka angažovanost najčešće nije bila ništa drugo do učestvovanje u radu društvenih polja moći koja su bila jemci sticanja simboličkog kapitala a time i umetničkog ugleda pisca.

Sve ovo govori u prilog tome da su se pisci u SFRJ, isto kao i pisci u postjugoslovenskom kulturnom prostoru, oduvek osećali delom intelektualnih elita: figura usamljenog pojedinca koji svojim individualnim stavom održava snagu kritičkog mišljenja bila je zapravo fingirana. Simbolički kapital i sve investicije u njega uložene vodile su inkluziji u hegemone grupe kojima je svakako pripadala i intelektualna elita. Intelektualac kao figura individualizma opstajao je samo kao retka ili virtuelna pojava: čak i najizuzetniji, poput npr. Radomira Konstantinovića, imali su ambivalentnu poziciju razapetosti između ideje o pobunjenom individuumu i društvene prakse elitizma kojoj su se priklanjali. Uostalom i sama je građanska koncepcija intelektualne delatnosti bila u samoj sebi podvojena između elitističkog konformizma i dekadentnog individualizma - samo ju je pozicija marginalizacije u komunističkom režimu SFRJ-a činila naizgled nekonformističkom.

Kritička uloga intelektualca individualističkog opredeljenja kao da se obnovila početkom devedesetih godina XX veka, uoči rasplamsavanja građanskog rata na prostorima bivše SFRJ. Intelektualci vezani za rad u humanističkim naukama, a ponajviše pisci poput $\mathrm{Du}$ bravke Ugrešić, Borisa Budena, Bore Ćosića, Predraga Matvejevića itd. napustili su prostor svojih ostrašćenih država i preuzeli poziciju slobodnih komentatora situacije raspada SFRJ sa distance, izveštavajući sa "ratom neugroženih područja”. Neki od intelektualaca su npr. emigrirali iz Srbije u susedne republike bivše SFRJ (Mirko Kovač, Svetlana Slapšak), a neki su pak ostali kod kuće zvanično objavivši unutrašnji azil i izolaciju poput već pomenutog Radomira Konstantinovića. Tenzija i ambivalencije nisu prestajale: pitanje investicija, kao i finansiranja, ovakvih "slobodnih pozicija" ostalo je nerešenim ali i otvorenim za debate u svetu sveopšteg kretanja kapitala. Čak ni dobro napisan tekst nije mogao odbraniti intelektualce od zahteva da objasne na koji su način uspeli da realizuju svoje "investicije" i novostečene pozicije. U eri globalizacije to je na izvestan način bilo obavezom, posebno što je postjugoslovenski kulturni prostor kao i trauma raspada SFRJ, ostao glavnom temom intelektualnog, spisateljskog i umetničkog opusa novih intelektualnih freelancera. Možda i zbog toga što je sve više intelektualaca i pisaca nastupalo sa pozicije političkih komentatora i/ili analitičara koji su svoje autorske kolumne pretvorili u prostore investicije radi sticanja onog simboličkog kapitala neophodnog za opstanak u jednoj široj, ne više lokalnoj već regionalnoj ili globalnoj neoliberalnoj kulturnoj zajednici.

Ova situacija ukazuje na usložnjavanje mreže društvenih polja u epohi globalizacije i balkanske tranzicije. Esnafskih interesa je sve više, a neki od njih su udruženi u prave (multi) nacionalne korporacije zadužene za proizvodnju diskursa o Balkanu i postjugoslovenskom političkom i kulturnom prostoru. Uloga intelektualaca u toj proizvodnji bila je i još je uvek dominantna: bilo da žive u državama na postjugoslovenskim prostorima, u dijaspori ili u privremenom egzilu, većina intelektualaca sa tih/ovih prostora ne može a da ne misli

14 Tatjana Rosıć, “Dnevnik 1941-1952 Aleksandra Tišme: Pandorina kutija i demoni odluke”, Intelektualci i rat 1939. - 1947. Zbornik radovas Desničinih susreta 2011. (ur. Drago Roksandić i Ivana Cvijović Javorina), Zagreb 2012., 57-70. 
traumu građanskog rata na kraju dvadesetog veka koja je dovela do stvaranja sasvim nove geopolitičke ali i geokulturološke i geojezičke, pa i geokonfesionalne mape Evrope. Ono što je predstavljalo, takođe, bizarnu novinu bila je veza između investiranja u sopstveni simbolički kapital i razumevanja/mišljenja sopstvenih ideološko-kulturološko-istorijskih trauma. Mazohističko okretanje, uvek iznova, mestu i uzrocima patnje, praćeno doživljajem intelektualne marginalizacije/bespomoćnosti pred događajima koji su se desili, predstavljalo je, $s$ jedne strane, onaj napor koji je Hana Arent u dokumentarnom filmu o njenom životu ovekovečila samo jednom rečenicom: "Sve što sam oduvek htela bilo je da razumem." ${ }^{15} \mathrm{~S}$ druge strane, pak, to je okretanje bilo na neki način iznuđeno globalnim zahtevom da se ima svedočiti ono što je ostatku sveta bilo nejasno ili nerazumljivo, nedostupno mišljenju - što zbog nepoznavanja činjenica što zbog kulturoloških razlika koje su onemogućavale kontekstualizaciju i razumevanje istih tih činjenica.

\section{Povraćaj odnosno profit: pitanje odgovornosti kao pitanje žanra}

Moć masovnih medija u procesu globalizacije donela je jednu jasno prepoznatliivu mogućnost koja se ispostavlja dvoseklim mačem u angažmanu intelektualca današnjice: intelektualni simbolički kapital može se, posredstvom medija, vrlo brzo "investirati" u druga polja društvene delatnosti pri čemu u tom transferu kapitala dolazi i do transformacije intelektualnog statusa i delovanja. Masovni mediji omogućili su relativno lako i brzo preusmeravanje intelektualnog delovanja iz polja stvaralačkog i kritičkog mišljenja u polje političkog delovanja i konkretne distribucije političke moći - ovo je preusmeravanje naročito značajno u humanističkim i društvenim naukama, kao i u pojedinim umetničkim disciplinama poput književnosti i/ili pozorišta. Odlika ovog transfera iz jednog u drugo simboličko polje društvenih praksi je i neprekidno re-investiranje i obnavljanje simboličkog kapitala na taj način što se iz jednog polja društveno-simboličkog delovanja neprekidno prelazi u drugo, i obratno: intelektualac koji je odavno založio svoje ime i javni ugled kao jemstvo svog odgovornog i kritičkog odnosa prema zajednici i na račun toga napravio zavidnu političku karijeru u određenim se trenucima/periodima vraća svojoj staroj ulozi "čistog" intelektualca - ova igra menjanja društvenih polja delovanja služi, $s$ jedne strane, obnavljanju intelektualnog kapitala, ali sa druge izbegavanju intelektualne odgovornosti. Jemstvo intelektualnog ugleda ovde je na sofisticirani način izigrano, a intelektualac postaje osoba sa višestrukim javnim identitetom: u kritičnim trenucima polaganja odgovornosti za svoje npr. političke postupke intelektualac se lako vraća u prvobitno polje svoga akademskog ili umetničkog delovanja da bi se, kad prođe bura, i ukoliko mu to mogućnosti dopuštaju, ponovo obreo u političkoj igri raspodele konkretne društvene moći. ${ }^{16}$

15 Film Hannah Arendt (rež. Margarethe von Trotta), 2012.

16 Burdijeova teorija društvenih polja pokazuje se dragocenom u razumevanju funkcionisanja savremenoga društvenog, političkog, kulturnog i naučnog potencijala intelektualnog polja, pre svega kada je reč o promenama u vezi sa stvarnošću globalnog sveta masovnih medija. Poznato je da je Burdije izrazio svoju doslednu sumnju u kritički potencijal društva masovnih medija te da je njegova knjiga o televiziji ukazivala na nemogućnost masovnih medija da se na bilo koji način kritički predoči stvarnost današnjice. Ipak, svoju polemiku sa urednicima emisije u kojoj je nastupao, kao i svoj angažman u borbi za prava radnika, nastavio je na stranicama dnevnog lista "Figaro" čiji se tiraž nikako nije mogao zanemariti niti bi se bilo koji štampani medij mogao isključiti iz pojma masovnih medija. Ili, rečeno rečni- 
Intelektualcima sa postjugoslovenskih kulturnih prostora nije strana dobrobit koju donosi carstvo masovnih medija iako nisu svi bili podjednako skloni medijskom angažmanu. Ipak, skoro svi koji drže do svog intelektualnog imidža pišu autorske kolumne ili komentare: žanr koji dominira svim oblicima štampanog i elektronskog novinarstva. Moglo bi se reći da je ovaj žanr zapravo postao omiljeni i dominantni žanr netabloidnog novinarstva koji zamenjuje istraživačko novinarstvo u odumiranju - iako su prisutne i u tabloidnim medijima, autorske su kolumne zapravo ponos netabloidnih medija koji imaju ambiciju rekonstituisanja platforme kritičkog mišljenja u javnosti. Spajajući privatni komentar sa temom od opšteg značaja autorska kolumna se pokazuje paradigmatičnim žanrom u kojem dominira napor razumevanja i trauma sećanja koji legitimišu tumače nove stvarnosti postjugoslovenskog kulturnog prostora.

Otuda ključno pitanje vezano za poziciju intelektualca danas jeste upravo pitanje njegovog/njenog pojavljivanja u medijima i njegovog/njenog aktivnog učešća u svetu proizvodnje značenja posredstvom masovnih medija. Šta se događa u trenutku kada kritički i čak aktivistički raspoložen intelektualac pristane na pakt sa jasno ocrtanim, i toliko puta kritikovanim, moćnim kapitalom multinacionalnih korporacija koji stoji iza sve dalekosežnije medijske (re)produkcije sveta u globalizaciji? Na koji način i u kojim pravcima masovni mediji omogućavaju transformaciju i transfer simboličkog kapitala koji poznati intelektualci današnjice "predaju" na privremeno korišćenje medijskim kućama? Da li je to korišćenje zaista "privremeno" ili omogućava neprekidnu (zlo)upotrebu intelektualnih resursa koja dovodi do obezvređenja i kompromitacije društvenog i simboličkog kapitala intelektualca današnjice? Postaje li intelektualac samo još jedan od medijskih zabavljača, čiji kritički diskurs biva poništen njegovom medijskom (zlo)upotrebom?

Kada je autorska kolumna u pitanju, najčešće jedan autor/autorka redovno piše ovaj privilegovani žanr za određene dnevne ili nedeljne novine ili elektronsko glasilo. Ponekad se dešava da autor/autorka piše istovremeno za više glasila ili da iz jednog glasila pređe u drugo. U svim ovim slučajevima relativno lako se može pratiti geneza žanra kao geneza pitanja odgovornosti vezanih za poziciju intelektualca na postjugoslovenskim prostorima danas. Možda bi jedan od najuzbudljivijih primera bila kolumna koju pisac (nekada i ambasador Srbije na Kipru i član danas nepostojeće Demohrišćanske partije Srbije) Svetislav Basara svakodnevno piše za opoziciono orjentisani dnevni list Danas. Basara, i u svom književnom opusu sklon satiri i parodiji kao i društvenoj kritici, zadržava poziciju koja zbunjuje naivnog čitaoca: pripovedač kolumne neprekidno biva pobrkan/zamenjen sa samim autorom, Svetislavom Basarom lično, i njegovom političkom biografijom. Basarin tekst tako predstavlja privilegovani autorski glas koji "bdi" nad "uspavanom" Srbijom, upozoravajući. ${ }^{17}$ Postoje naravno i drugi primeri: spisak autora koji pišu za elektronsko izdanje Peščnika ukazuje na strateški dosledan i dalekosežan projekt koji bi trebalo da obnovi platformu kritičkog

kom Gi Debora, mehanizmi društva spektakla toliko su moćni i podrobno razvijeni da je nemoguće da se u okviru medijskog sveta, koji podrazumeva sliku kao vrhunac simulakruma, na bilo koji način svetu uputi kritička poruka o njemu samome - ta "istina" samo je još jedan od elemenata simulakruma koji društvo spektakla predočava kao "stvarnost" savremenog sveta. Ipak, kao što je Burdije učestvovao u televizijskim emisijama, tako je i Debor snimao filmove. Iako eksperimentalni, ti su filmovi, zahvaljujući radikalnom životnom konceptu koji je Debor odigrao do kraja, stekli neprocenjiv kultni status. Čini se, na osnovu samo ova dva primera, a moglo bi se naći još mnogo njih - televizijska emisija o Žaku Lakanu, Deridini i Delezovi televizijski intervjui i, najsvežiji primer, filmovi o Slavoju Žižeku u kojima Žižek nastupa kao narator i za koje piše scenario - da su i najkritičniji među intelektualcima druge polovine dvadesetog i prve dve decenije dvadeset prvog veka pokazali razumevanje za svoju slavu, omogućujući joj da dobije i svoj neminovni, epohalno prepoznatljivi, medijski oblik.

17 Up. kolumne Svetislava Basare u dnevnom listu Danas (http://www.danas.rs/code/navigate.asp?Id=881). 
mišljenja u regionu. U ovom projektu učestvuju brojni autori koji ne odustaju od ideje kritičkog promišljanja stvarnosti putem otvorenog i medijski promovisanog autorskog stava, poput istaknutih hrvatskih kolumnista (Viktor Ivančić, Boris Dežulović, Predrag Lucić), sarajevskih pisaca (Aleksandar Hemon, Nenad Veličković) i srpskih pravnika, pisaca i izdavača. U poslednje vreme elektronsko izdanje Peščanika pokušava da redefiniše svoje promišljanje stanja u regionu rekontekstualizacijom tekstova u širi diskurs kritike globalnog neoliberalnog kapitalizma. Ipak, na sajtu Peščanika objavljuje i čitav niz autorki i autora (npr. Vesna Pešić) koji imaju ozbiljne političke biografije (u kojima su ambasadorske funkcije samo neke od značajnijih), pri čemu kao da se posledice njihovog aktivnog učešća u političkom odlučivanju ne uzimaju u obzir u ovoj igri pisanja u kojoj pojedini autori nastupaju kao da su politički potpuno nevini, kao da nikada nisu imali nikakvu izvršnu moć i kao da posledice njihovog (ne)odlučivanja nisu određivale sudbinu čitave zajednice. ${ }^{18}$

Primeri su raznovrsni i ima ih pregršt. No za sve je zajednički specifičan povraćaj uloženog simboličkog kapitala koji se pisanjem autorske kolumne ostvaruje - profit se ovde isplaćuje u etičkoj valuti, u sticanju privida one reputacije koja autorima daje moralni legitimitet da prosuđuju stvarnost postjugoslovenskog kulturnog i političkog prostora. Kako je, međutim, taj moralni profit ostvaren, tj. kako je zadobijen taj etički legitimitet sa kojim autori kolumni nastupaju u javnosti? Autorska je kolumna mesto očigledne transakcije na kome se odvija transfer i obrt iz jednog oblika simboličkog kapitala u drugi: privatni uvid zasnovan na ličnoj traumi/sećanju razmenjuje se za diskurs od opšteg značaja u kome autor učestvuje kao kompetentni (a ponekad i kao jedini kompetentni) (sa)govornik. Autor se posredstvom svoje kolumne preobraćuje u političkog analitičara i tumača društvene stvarnosti koji bi trebalo da nam skrene pažnju na anomalije iste one društveno-kulturne javnosti koja je proizvela žanr kolumne kao privilegovani žanr. U okviru samo jednog teksta dešava se pomeranje investicije iz jednog društvenog polja u drugo: iz društvenog polja akademskog diskursa ili umetničkog stvaranja autor kolumne preusmerava, i time re-investira, svoj simbolički kapital u društveno polje medija, pri tome vodeći računa o prirodi esnafskog udruživanja u okviru ovog polja, tj. o prirodi esnafskog udruživanja vezanoj za konkretni medij u kome se oglasio i za prava vlasništva njemu svojstvena koja određuju uređivačku politiku medija i profil publike kojoj se obraća. Na taj način se "slobodni" intelektualni angažman preobraća u transakciju u kojoj se "simbolički" i "intelektualni" kapital, kao i svi drugi oblici kapitala, realizuje tek u svom "idealnom" obliku neprekidnog kretanja i transformacije: interesantno je da čak i tako mali simbolički prostor, kakav je prostor autorske medijske kolumne, omogućava brzu i uspešnu transakciju u kojoj kapital menja svoju formu i svoju svrhu investiranja. Pomislilo bi se, čak, da je autorska kolumna paradigma sveopšteg kretanja, investiranja i re-investiranja kapitala (dakako simboličkog) koja je idealna upravo zbog svojih žanrovskih mikro svojstava koja - u tajnoj narativnoj formuli - sažimaju pravila transakcije simboličkog kapitala na neoliberalnom tržištu kulturnih proizvoda i intelektualnih usluga.

Zato budimo oprezni: zadovoljstvo koje nalazimo u čitanju kolumne najčešće je rezultat privida reformističkog građanskog intelektualnog angažmana - onog angažmana koji je, zapravo, doživeo poraz i pokazao se neadekvatnim načinom delovanja u neokolonijalnim uslovima procesa globalizacije. Moramo se upitati kako to da je dominantni žanr u svetu masovnih medija zapravo žanr prošlosti i zbog čega je on toliko omiljen u društvima koja,

18 Up. multimedijalni portal Peščanik (http://pescanik.net/). 
s druge strane, vape za promenom i novim aktivizmom? Nije li reč o sofisticiranom izbegavanju odgovornosti upravo u okviru jednog hibridnog žanra koji se zalaže za podizanje svesti o neophodnosti privatnog angažmana u pitanjima od javnog značaja; i to onog žanra koji, zahvaljujući plauzibilnoj granici u okviru opozicije privatno/javno, uočava i u tzv. malim stvarima razlog za protest i kritički odnos prema okruženju. $U$ tom smislu autorska kolumna postaje paradoksalni žanr/mesto pomodnog i konformističkog, zgodna za olako promovisanje novih, alternativnih i subkulturnih životnih stilova: ona je poprište borbe za ekološko okruženje, očuvanje prirodnih lepota, manjinska prava, poštovanje nacionalne i internacionalne baštine, makrobiotiku i vegetarijansku zdravu ishranu, zdrav život uopšte ali i za poštovanje razlike i razumevanje onih koji jedu meso, puše, ne vežbaju dovoljno ili ne vežbaju uopšte, ne idu na koncerte i na izložbe ali gledaju reality programe itd.

Autorska kolumna je žanr koji, dakle, promoviše toleranciju u svakom pogledu, uz mrvicu ironije i sarkazma, koji bi trebalo da nam ukažu na to da nas je postmodernistička tolerancija dovde i dovela. U svetu u kome više od polovine planete nema nikakvu šansu da uopšte sanja o bilo kakvom "životnom stilu" autorska kolumna samo je još jedan uspešno pronađeni način za umirenje građanske savesti; privid koji odlaže konačno priznanje poraza građansko-liberalnog intelektualnog obrasca za koji se većina autora kolumni zapravo zalaže. Paralelno sa ovim diskursom u postjugoslovenskom kulturnom prostoru još uvek je vrlo uticajna tradicionalna predstava o širini intelektualnog delovanja i višestrukom identitetu intelektualca/stvaraoca koja omogućava da se iz igre zvane "briga za dobrobit zajednice" privremeno povuku investicije kako bi se ponovo, sa podignutom vrednošću, uložile u ugled nečijeg "nezavisnog" umetničkog/intelektualnog lika i dela. Interesantno je da ovo "odstupanje" sa politički i ekonomski istaknute pozicije javnog delatnika ne pokreće nikakva pitanja o njegovoj odgovornosti: automatski se prihvata da je on samo privremeno zapostavio svoj "sveti" umetnički ili intelektualni angažman zarad "brige za zajednicu" koja mu je, naravno, donela vrlo veliku ali u javnim raspravama nikad spominjanu finansijsku dobit. Autorska kolumna u ovom kontekstu se čita kao uobičajena "dopunska" delatnost umetnika/intelektualca koji se zahvaljujući njoj "odmara" od napornog i "genijalnog", "pravoga” profesionalnog posvećenja; do prve sledeće, zgodne političke prilike.

Društva postjugoslovenskog tranzicionog prostora suočena su, skoro svakodnevno, sa ovakvim transferima intelektualnog kapitala i njihovim transformacijama koje prate promenu kritičkog u ideološko-izvršni diskurs. Izmicanje od odgovornosti i promena identitetske pozicije utoliko je lakše ukoliko se ima u vidu da je u srpskoj ali i u postjugoslovenskoj kulturi još uvek vrlo snažna, skoro dominantna, univerzalistička koncepcija estetskih i intelektualnih vrednosti dela u kojoj se - u građanskoj tradiciji visokih dometa evropske moderne - zanemaruje specifičnost istorijsko-ideološkog konteksta u kome opus nastaje, kao i suštinski aktivistički aspekt akademskih uvida kulturnih, medijskih i postkolonijalnih studija o značaju tog konteksta. Tako npr. u srpskim akademskim zajednicama ima sve više onih koji u svojim akademskim radovima svesrdno citiraju teoretičare postkolonijalnih studija, a u svom se političkom i medijskom nastupu zalažu za univerzalističke principe vrednovanja umetničkog dela i intelektualnog opusa, insistirajući na autonomiji estetskih vrednosti nezavisnoj od bilo kakve ideološke interpretacije ili interpelacije. Nova "teorijska obuka" - u okviru koje se rodne i postkolonijalne studije konačno prihvataju kao akademske discipline, a feministička kritika uspeva da se struktuira kao samostalni kritički diskurs - došla je dve decenije prekasno. Rat je gotov, a raspad i podela SFRJ završeni. Pri tome ni teorijska obuka nije najbolje "sprovedena": univerzalisti koji citiraju eminentne radove iz 
postkolonijalnih, kulturnih i rodnih studija čine to radi pukog akademskog prestiža. Oni i dalje ne vide u čemu je zapravo veza između radova koje citiraju te srpskog i postjugoslovenskog društvenog i kulturnog prostora.

Štaviše, čini se da većina njih misli kako te veze zapravo i nema. Čini se, naime, da većina njih i dalje živi u ubeđenju, uprkos iskustvu traumatske prošlosti raspada SFRJ na kraju XX veka, da doba građanske Evrope još nije prošlo i da će tek doživeti svoj zenit. Mazohizam sticanja odvija se kao u nekom začaranom, perpetum mobile procesu: oni koji investiraju u sopstvenu traumu kao da veruju da će simbolički kapital na taj način stečen biti iskupljujući. Kao da "goli život" već nije stupio na istorijsku i političku pozornicu Evrope, kao da se već i naši sopstveni životi ne ogledaju u tom agambenovskom prizoru.

\section{Crni panteri i Agamben}

Angažman novih intelektualnih elita koje se formiraju tokom devedesetih i posle dvehiljadite na postjugoslovenskim prostorima se, iz brojnih razloga, pokazao nedostatnim: zauzeti investiranjem u svoje karijere u širem kontekstu globalnog kulturnog tržišta intelektualci su zaboravili na brigu o građanima i njihovoj zajednici, kao i na ozbiljnu reformu građanske platforme kritičkog mišljenja. U ovakvoj je situaciji intelektualni ugled davno prevaziđena i zapravo izigrana kategorija koja je stavljena u tržišnu ponudu: reč je o situaciji na koju je neophodno hitno reagovati kako bismo posle više decenija ćutanja odgovorili na pitanje šta je danas zapravo jemstvo intelektualnog ugleda i da li nam je taj ugled, takav kakav je, garancija istinskog delovanja u korist zajednice.

Tek početkom druge decenije dvadeset prvog veka javili su se glasovi pobune protiv ovakvog sticanja simboličkog kapitala. Teoretičari nove generacije, poput Damira Arsenijevića, zalažu se za prevazilaženje traumatske investicije u procesu sticanja simboličkog kapitala jer je po njima to uvek investicija u prošlost, vođena nekrofilnom politikom koju su uspostavili kolonizatori, a ne žrtve. Otuda Arsenijević piše:

Od kraja rata, 1995, umjesto da ožale užasne gubitke, građani i građanke Bosne i Hercegovine prisiljavani su, čas od lokalnih, čas od internacionalnih faktora, da prihvate kako mogu govoriti jedino kao žrtve na čijim tijelima etničke elite zidaju perverzna bogatstva.

Protesti su napravili, po prvi put, šansu za Bosnu i Hercegovinu - da se makne od melanholije ka žalovanju; to jest: da se suoči sa gubicima i počne prebrojavati ratne dobitke. Život koji je nadživio rat i genocid, život koji osjeća duboko nepovjerenje dok istovremeno očekuje spas, život koji je bio brutaliziran korumpiranom privatizacijom javnih preduzeća, život koji sanja jedino o napuštanju ove zemlje, život koji zna da je jedino sigurno umiranje od samoće i gladi - to je naš život, život koji moramo sabrati da stvorimo iznova humanije društvene veze. To je taj život, onaj koji se u agoniji i boli odriče nepovjerenja i radi neumoljivo da proizvede i oproba drugačiju mogućnost. ${ }^{19}$

Svoj tekst Arsenijević je postavio na elektronskom portalu sarajevskog Medija centra tokom poslednjih nemira u $\mathrm{BiH}$. Ovaj glas podignut je upravo pred prizorom u kome se u procesu neokolonizacije svi naši životi, posmatrano iz globalne perspektive, pretvaraju

19 Damir Arsenijević, "Proizvodnja i vježbanje mogućnosti” (http://www.media.ba/bs/magazin-etika/proizvodnja-ivjezbanje-mogucnosti). 
u Agambenov "goli život", a svi mi postajemo Agambenovi "muslimani". Pre nego što se takva sadašnjost zaista desi, sadašnjost koja će nam ukinuti budućnost, na ulicama i na proglasima, kao i u nekim umetničkim i akademskim radovima, ukazalo se na potrebu za pobunom, kao i za novom idejom o intelektualnom angažmanu - za intelektualcem-revolucionarom koji će tu pobunu izvesti, osvajajući ponovo pretpostavke o stvaranju društva oslobođenog straha. Otuda se u ovom tekstu ne pojavljuje agambenovska figura "golog života" već figura borbe za život koji će oprobati i "drugačije mogućnosti”. Ovaj tekst zahteva da svaki intelektualni angažman postane koliko svakodnevni toliko i revolucionarni: intelektualac mora odustati od kalkulacije sopstvenom traumom, od mazohizma sticanja, od transakcija ugledom, od transfera iz jedne u drugu značajnu tačku društvene moći ukoliko želi da se suoči sa budućnošću slobode. Ili kako to Salman Rušdi ističe:

Kreativni čin zahtijeva ne samo slobodu, već i ovu pretpostavku o slobodi. Ako umjetnik brine da li će sutra biti slobodan, onda on nije slobodan ni danas. Ako se plaši posljedica svog izbora teme ili načina na koji ju je obradio, onda njegovim izborom neće upravljati njegovog talenat, već njegov strah. Ako nismo sigurni u svoju slobodu, onda nismo slobodni. ${ }^{20}$

Mislite li da to na prostorima bivše Jugoslavije zvuči kao da smo jednom probali, ali nam nije uspelo i zbog toga moramo odustati svaki put iznova? Razmislite. Ako se vratimo na početne pretpostavke ovog teksta setićemo se da on ima i moto. Radi se o pesmi koju je Gil Skot-Heron napisao uzevši za refren slogan Crnih pantera, grupe koja se sedamdesetih godina XX veka na radikalan način, koristeći se i terorističkim strategijama, borila za prava Afroamerikanaca. Gil Skot-Heronova pesma posvećena je, u svojoj osnovi, obračunu sa hipnotičkom moći masovnih medija i konzumentskog društva koje struktuira mit o američkom snu i malograđanski američki milje. Ona upozorava da će se revolucija desiti uprkos reklamama, tv serijama u nastavcima, kokicama i koka-koli koje konzumiramo dok gledamo crtiće, sugerišući da je drugačija stvarnost, stvarnost koja će se odigrati na drugom mestu i na drugačiji način od onog na koji smo navikli - moguća. Crni panteri su mahom završili svoje živote nasilnom smrću ili u zatvoru. Njihova grupa, kao i njihovo političko delovanje, trajala je kratko. Činilo se da se na taj način ništa ne može promeniti. Ipak, prava Afroamerikanaca su osvojena. U dugoj borbi za ta prava povest o Crnim panterima nikada nije izgubila svoju mitsku dimenziju i svoju motivacionu moć. Ona je potvrđivala da su revolucionari zaista postojali i da nije uzaludno verovati u neophodnost takvog oblika društvenog angažmana. Takođe, ona je ukazala na to da je strah najveći neprijatelj promene: zbog toga su mitski heroji afro-američke borbe za prava bili upravo oni koji su odbili da žive u kulturi straha.

Sve to kazuje nam nešto o potrebi rekonstituisanja figure intelektualca-revolucionara u postjugoslovenskom kulturnom prostoru koja se neće temeljiti u skandalu prividne intelektualne pobune koji je medijski fotogeničan. Svrha delovanja intelektualca-revolucionara je zbuniti medije nesviknute na revoluciju i na izvestan način paralisati njihovo upravljanje procesom sticanja intelektualnog simboličkog kapitala. Jer, kao što to imamo priliku da vidimo širom sveta, kamera ne zna tačno šta snima na ulicama Sirije, Ukrajine, Sarajeva ili Tuzle. Nove revolucije ne daju se više prikazati bezbolno, one nisu

20 Salman Rushidie, "Umjetnost nije zabava, umjetnost je revolucija” (http://www.e-novine.com/kultura/kulturatema/64800-Umjetnost-nije-zabava-umjetnost-revolucija.html). 
snimak Zalivskog rata koji liči na video igru i koji gledaoce ostavlja ravnodušnim, kako je upozoravao Bodrijar. ${ }^{21}$

Nove revolucije zbunjuju kameru i nisu fotogenične. Nove revolucije blokiraju masovne medije, nove medije i linkove koji bi nas lako i odmah odveli do informacija. Nove revolucije ne mogu se prevesti na diskurse konzumacije/kolonizacije i o njima se još ne može svedočiti. One nas provociraju i zahtevaju da sami tragamo, kontaktiramo i angažujemo se kako bismo saznali šta se zapravo dešava. Na izvestan način to je poziv da se priključimo i podržimo promenu koja se pokušava (samo)artikulisati.

Jer možda smo i mi među onima koji su suviše dugo čekali da isprobaju, stvarno isprobaju, istinske mogućnosti intelektualnog angažmana u epohi globalnog jada. Jer: "Umjetnost nije zabava. U svom najboljem izdanju, ona je revolucija."22

\section{cos}

\section{Reputation for Sale: Intellectuals, Citizens and REVOLUTIONARIES}

The engagement of the new intellectual elite which formed during the1990s and early 2000s on the territory of former Yugoslavia proved inadequate for many different reasons: busy building their careers in the broader context of the global cultural market, intellectuals contributed to the deterioration of the concept of civil society and to numerous failed attempts to reform the civil platforms of critical thinking. However, the intellectual elite remained devoted to archaic forms of civic engagement and their own social conformism. In post-Yugoslav media the editorial represents the privileged media genre and a platform for engagement and a precise formula of rapid transformation of the symbolic into political power. It was only at the beginning of 2010s that the voices of rebellion against such a situation emerged, accusing the acquisition of symbolic capital by accepting the rules of the neoliberal market-cultural capitalism. Theorists of the younger generations advocate the overcoming of the trauma of investment in the process of acquiring symbolic capital. According to them, it is always an investment in the past, led by necrophiliac policies set up by the colonizers - not by the victims. Therefore the new concept of political engagement does not concern Agamben's concept of "bare life" but the possibility of creating a different social and political reality in the post-Yugoslav cultural space. All this points to the need to reconstitute the figure of the intellectual as a revolutionary in the post-Yugoslav cultural space, the figure which would deal with the future of intellectual freedom and denounce the intellectual calculations with traumatic memories, masochism of symbolic capital acquisition, transaction with intellectual reputation, and the transfer from one to another important point of social power. The new type of engagement should be based in rebellion which will confuse the media and prevent their domination over the process of acquiring intellectual and symbolic capital.

Keywords: the intellectual, citizen, revolutionary, globalization, post-Yugoslav cultural space, mass media, engagement, symbolic capital

\section{$\cos$}

21 Žan Bodrijar, "Rat u Zalivu se nije dogodio", Evropski diskurs rata, Zbornik radova (ur. Obrad Savić), Beograd 1995., 463-482.

22 S. Rushidie, "Umjetnost nije zabava, umjetnost je revolucija". 


\section{Literatura}

Đorđo Agamben, Homo sacer: suverena moć i goli život, Loznica 2013.

Damir Arsenijević, "Proizvodnja i vježbanje mogućnosti" (http://www.media.ba/bs/magazinetika/proizvodnja-i-vjezbanje-mogucnosti).

Svetislav Basara, kolumne u dnevnom listu Danas (http://www.danas.rs/code/navigate. asp?Id $=881$ ).

Zigmunt Bauman, Fluidni strah, Novi Sad 2010.

Žan Bodrijar, "Rat u Zalivu se nije dogodio", Evropski diskurs rata, Zbornik radova (ur. Obrad Savić), Beograd 1995., 463-482.

Boris Buden, Zona prelaska, Beograd 2012.

Pjer Burdije, Pravila umetnosti: geneza i struktura polja književnosti, Novi Sad 2003.

Guy DeвоRD, "Društvo spektakla" (http://anarhisticka-biblioteka.net/library/guy-debord-drustvospektakla).

Mladen Dolar, O škrtosti i o nekim sa njom povezanim stvarima, Zagreb 2009.

Henry A. Giroux, Beyond the Spectacle of Terorism, London 2006.

Daglas Kelner, Medijska kultura, Beograd 2004.

Naomi KLAJN, Doktrina šoka: procvat kapitalizma katastrofe, Beograd 2009.

Peščanik (http://pescanik.net/).

Tatjana Rosıć, "Dnevnik1941-1952 Aleksandra Tišme: Pandorina kutija i demoni odluke", Intelektualci i rat 1939. - 1947. Zbornik radova s Desničinih susreta 2011. (ur. Drago Roksandić i Ivana Cvijović Javorina), Zagreb 2012., 57-70.

Salman Rushdie, "Umjetnost nije zabava, umjetnost je revolucija" (http://www.e-novine.com/kultura/kultura-tema/64800-Umjetnost-nije-zabava-umjetnost-revolucija.html).

Ričard SeneT, Kultura novog kapitalizma, Beograd 2007.

Gajatri Čakravorti SPIVAK, Teorija postkolonijalnog uma, Beograd 2003.

Pol Virilio, Mašine vizije, Novi Sad 1993.

Dubravka Ugrešrć, Kultura laži, Beograd 2012.

\section{Filmovi}

Hannah Arendt (rež. Margarethe von Trotta), 2012.

Derrida (rež. Kirby Dick i Amy Ziering), 2002.

Jacques Lacan: Television (rež. Benoît Jacquot), 1973.

L'abecedaire de Gilles Deleuze (rež. Pierre-André Boutang), 1996.

The Perverts Guide to Ideology (rež. Sophie Fiennes, scen. Slavoj Žižek), 2012. 